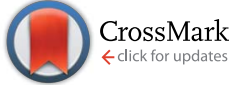

Cite this: RSC Adv., 2017, 7, 17697

\title{
Synthesis, structure and gas adsorption properties of a stable microporous Cu-based metal-organic framework assembled from a T-shaped pyridyl dicarboxylate ligand $\uparrow$
}

\author{
Di Wang, Libo Sun, Yuchuan Liu, Jianfeng Du, Shun Wang, Xiaowei Song* \\ and Zhiqiang Liang*
}

A three-dimensional microporous metal-organic framework assembled from a T-shaped pyridyl dicarboxylate ligand, 4'-(pyridin-4-yl)-[1,1'-biphenyl]-3,5-dicarboxylic acid ( $\left.\mathrm{H}_{2} \mathrm{PBPD}\right)$, has been successfully synthesized via solvothermal reaction with copper(॥) nitrate. Compound 1 was characterized by X-ray single-crystal diffraction, elemental analysis, IR spectroscopy and thermogravimetric analyses. Single-crystal $X$-ray diffraction analysis indicates that compound 1 is a $(3,6)$-connected threedimensional framework with the point symbol $\left\{4^{2} \cdot 6\right\}_{2}\left\{4^{4} \cdot 6^{2} \cdot 8^{6} \cdot 10^{3}\right\}$. In the framework of this compound, there exist two large metal-ligand cages. Stability tests show that compound 1 keeps its crystal structure after being soaked in several organic solvents or calcined at $250{ }^{\circ} \mathrm{C}$ under air atmosphere. The $\mathrm{N}_{2}$ adsorption at $77 \mathrm{~K}$ shows that compound 1 is microporous with a BET surface area of $1682 \mathrm{~m}^{2} \mathrm{~g}^{-1}$. Compound 1 possesses high adsorption capacities for $\mathrm{CO}_{2}\left(114 \mathrm{~cm}^{3} \mathrm{~g}^{-1}, 273 \mathrm{~K}\right)$ under ambient pressure. The test of $\mathrm{CO}_{2}$ cyclic adsorption and regeneration of 1 shows that it has a stable $\mathrm{CO}_{2}$ adsorption capacity and no obvious weight change after doing this ten times.

Received 25th January 2017
Accepted 10th March 2017

DOI: $10.1039 / c 7 r a 01125 c$

rsc.li/rsc-advances
The structure and properties of MOFs can be rationally designed and improved through several effective approaches such as incorporation of open metal sites, ligand functionalization, framework interpenetration and polar pore walls. ${ }^{5}$ Generally, the pores of MOFs are filled with terminal and free solvent molecules, which could be removed by solventexchanged and thermal treatment to generate open metal sites. Functionalized organic ligands can be obtained by introducing some groups, such as $-\mathrm{NH}_{2},-\mathrm{OH},-\mathrm{CH}_{3}$ and pyridyl groups. ${ }^{6}$ And it is worth noting that embedding Lewis basic pyridyl sites into the pore walls of MOFs can drastically impact their gas uptake capacity and selectivity, especially for the $\mathrm{CO}_{2}$ capture, which is because there are dipole-quadrupole interactions between the polarizable $\mathrm{CO}_{2}$ molecule and the nitrogen site. $^{7}$ In addition, the coordination modes of ligands with specific symmetries are a key factor in the structures and properties of the final products.

In recent years, MOFs with carboxylate-containing ligands which contain mixed N-, O-donors have been extensively studied. Among these ligands, the $\mathrm{N}$-donors mainly come from compounds with coordination such as pyridine, imidazole, triazole and so on, and the O-donors come from groups $-\mathrm{COOH}$, -OH or nitrogen oxides. ${ }^{8}$ A series of T-shaped pyridyl dicarboxylate ligand such as 5-(pyridin-4-yl)isophthalic acid, (E)-5-(pyridin-4yl-methyleneamino)isophthalic acid, 5-(isonicotinamido)isophthalic acid, 5-[(pyridin-4-ylmethyl)amino]isophthalic acid, 5-(4-
State Key Lab of Inorganic Synthesis and Preparative Chemistry, Jilin University, Changchun, 130012, P. R. China.E-mail: liangzq@jlu.edu.cn; xiaoweisong@jlu.edu. $\mathrm{cn}$

$\dagger$ Electronic supplementary information (ESI) available: Complete X-ray crystallographic data for $\mathbf{1}$ in CIF format. PXRD patterns, TGA and IR spectra for 1. Selected bond lengths and angles for compound 1. CCDC 1471464. For ESI and crystallographic data in CIF or other electronic format see DOI: 10.1039/c7ra01125c 
pyridyl)-methoxyl isophthalic acid and $4^{\prime}$-(1H-tetrazol-5-yl)-[1,1'biphenyl]-3,5-dicarboxylic acid ( $\mathrm{H}_{3}$ TZBPDC), etc. have been used to construct new structures with diverse properties. ${ }^{9}$ This type of ligands were selected based on the following considerations: (1) carboxylate groups and pyridine nitrogen donors in the ligand can take part in coordination as bridging ligands to form metalcarboxylate clusters, such as dinuclear, trinuclear, and even higher nuclear clusters; (2) pyridyl donor organic ligands can complement the dicarboxylate ligands in the coordination and formation of high-connected nets; (3) the N-donors from the ligands can coordination with the metal cations, forming much stronger metal-N bonds, which would enable the high stability of the resultant MOF.

By taking account of the above-mentioned factors, we designed and synthesized a novel T-shaped pyridyl dicarboxylate ligand named $\quad 4^{\prime}$-(pyridin-4-yl)-[1,1'-biphenyl]-3,5-dicarboxylic acid $\left(\mathrm{H}_{2} \mathrm{PBPD}\right)$ via Suzuki coupling reaction in this work. Based on the $\mathrm{H}_{2}$ PBPD ligand, a stable three-dimensional microporous metalorganic framework $\left[\mathrm{Cu}(\mathrm{PBPD})(\mathrm{DMF})_{2}\left(\mathrm{H}_{2} \mathrm{O}\right)_{3}\right]$ (1) has been successfully synthesized via a solvothermal reaction with copper(II) nitrate. In the framework of this compound, there exist two large metal-ligand cages. We explored the stability and adsorption capacity of compound 1 . The stability analyses indicates that compound $\mathbf{1}$ can keep its crystal structure after being soaked in several organic solvents or calcined at $250{ }^{\circ} \mathrm{C}$ under air atmosphere, and even after cycle more than 10 times. The $\mathrm{N}_{2}$ adsorption at $77 \mathrm{~K}$ shows compound $\mathbf{1}$ is microporous with BET surface area of $1682 \mathrm{~m}^{2} \mathrm{~g}^{-1}$. And compound 1 possesses high adsorption capacities for $\mathrm{CO}_{2}\left(114 \mathrm{~cm}^{3} \mathrm{~g}^{-1}, 273 \mathrm{~K}\right)$ under ambient pressure. In preparation of this paper, Bai et al. reported a similar MOF showing good $\mathrm{CH}_{4}$ storage capacity under high pressure. ${ }^{10}$

\section{Experimental section}

\section{Materials and physical characterizations}

Except for the $\mathrm{H}_{2} \mathrm{PBPD}$ ligand, all other chemicals and solvents were obtained from commercial sources and used as received without further purification. Powder X-ray diffraction (PXRD) data were collected on a Rigaku D-Max 2550 diffractometer using $\mathrm{Cu}-\mathrm{K} \alpha$ radiation $(\lambda=0.15418 \mathrm{~nm})$ and $2 \theta$ ranging from 4 to $40^{\circ}$ at room temperature. IR spectra were recorded on a Nicolet Impact 410 FTIR spectrometer as $\mathrm{KBr}$ pellets in the $400-4000 \mathrm{~cm}^{-1}$ region. Thermogravimetric analyses (TGA) data were recorded on Perkin-Elmer TGA Q500 thermogravimetric analyzer under an air atmosphere from room temperature to $800{ }^{\circ} \mathrm{C}$ (heating rate of $10^{\circ} \mathrm{C} \mathrm{min}{ }^{-1}$ ). Elemental microanalyses (C, $\mathrm{H}$ and $\mathrm{N}$ ) were carried out using a Perkin-Elmer 2400 elemental analyzer. The point symbol and topological analysis were conducted using the TOPOS 4.0 program package. ${ }^{11}$

\section{Crystal structure determination}

The diffraction data of compound $\mathbf{1}$ were collected on a Bruker AXS SMART APEX-II diffractometer with graphite monochromated Mo $\mathrm{K} \alpha$ radiation $(\lambda=0.71073 \AA)$ at $298 \mathrm{~K}$. Date processing was completed with the SAINT processing program. ${ }^{12}$ The crystal structures was solved by direct methods, and refined anisotropically on $F^{2}$ by the full-matrix least-squares technique using the SHELXL-97. ${ }^{13}$ All non-hydrogen atoms were refined anisotropically. The hydrogen atoms on the aromatic rings were geometrically placed with isotropic thermal parameters 1.2 times that of the attached carbon atom. The diffraction data of compound 1 were collected by using the SQUEEZE routine of PLATON to remove the contribution of disordered molecules. ${ }^{14}$ Crystallographic data for compound $\mathbf{1}$ are summarized in Table S1, $\uparrow$ while the selected bond lengths and angles are list in Table S2. $\dagger$ More details on the crystallographic studies as well as atom displacement parameters are presents in the CIF.

\section{Synthesis of $4^{\prime}$-(pyridin-4-yl)-[1,1'-biphenyl]-3,5-dicarboxylic acid $\left(\mathrm{H}_{2} \mathbf{P B P D}\right)$}

The synthetic route of compound 1 is shown in Scheme 1. To a solution of dimethyl 5-iodoisophthalate $(320 \mathrm{mg}, 1.0 \mathrm{mmol})$ in DMF $(5 \mathrm{~mL})$ were sequentially added 4-bromophenylboronic acid $(210 \mathrm{mg}, 1.05 \mathrm{mmol}), \mathrm{Pd}(\mathrm{PhCN})_{2} \mathrm{Cl}_{2}(20 \mathrm{mg}, 0.053 \mathrm{mmol})$ and $\mathrm{K}_{2} \mathrm{CO}_{3}(400 \mathrm{mg}, 2.90 \mathrm{mmol})$ under $\mathrm{N}_{2}$. After 12 hours stirred at $80{ }^{\circ} \mathrm{C}$ under $\mathrm{N}_{2}$, the reaction was quenched with water, extracted with ethyl acetate, washed with brine and dried over $\mathrm{MgSO}_{4}$. Evaporation and flash column chromatography on a silica gel (petroleum ether-ethyl acetate $=10: 1$ ) gave the coupling product M1 $(180 \mathrm{mg}, 0.52 \mathrm{mmol})$ in $52 \%$ yield as a pale solid. ${ }^{1} \mathrm{H}$ NMR $\left(300 \mathrm{MHz}, \mathrm{CDCl}_{3}\right): \delta=8.66(\mathrm{t}, J=1.5 \mathrm{~Hz}, 1 \mathrm{H})$, $8.42(\mathrm{~d}, J=1.8 \mathrm{~Hz}, 2 \mathrm{H}), 7.50-7.64(\mathrm{~m}, 4 \mathrm{H}) .{ }^{13} \mathrm{C}$ NMR $(75 \mathrm{MHz}$, $\left.\mathrm{CDCl}_{3}\right): \delta=166.1,140.8,138.0,132.2,132.0,131.4,129.6,128.7$, 122.7, 52.5. Anal. calcd for $\mathrm{C}_{16} \mathrm{H}_{13} \mathrm{BrO}_{4}: \mathrm{C}, 55.04 ; \mathrm{H}, 3.75$. Found: C, 55.03; $\mathrm{H}, 3.51$. MS $m / z: 351.0\left(\mathrm{M}+\mathrm{H}^{+},{ }^{81} \mathrm{Br}\right), 349.0(\mathrm{M}+$ $\left.\mathrm{H}^{+},{ }^{79} \mathrm{Br}\right)$.

To this product of M1 $(710 \mathrm{mg}, 2 \mathrm{mmol})$, dissolved in DMF $(10 \mathrm{~mL})$, were added pyridin-4-ylboronic acid $(370 \mathrm{mg}, 3 \mathrm{mmol})$, $\mathrm{Pd}\left(\mathrm{PPh}_{3}\right)_{4}(231 \mathrm{mg}, 0.2 \mathrm{mmol})$ and $\mathrm{K}_{2} \mathrm{CO}_{3}(552 \mathrm{mg}, 4 \mathrm{mmol})$ under $\mathrm{N}_{2}$. After stirring at $120{ }^{\circ} \mathrm{C}$ under $\mathrm{N}_{2}$ for 12 hours, the reaction was quenched with water, recrystallized with ethyl acetate, gave the coupling product dimethyl 4 '-(pyridin-4-yl)[1,1'-biphenyl]-3,5-dicarboxylate (M2) $(426 \mathrm{mg}, 1.22 \mathrm{mmol})$ in

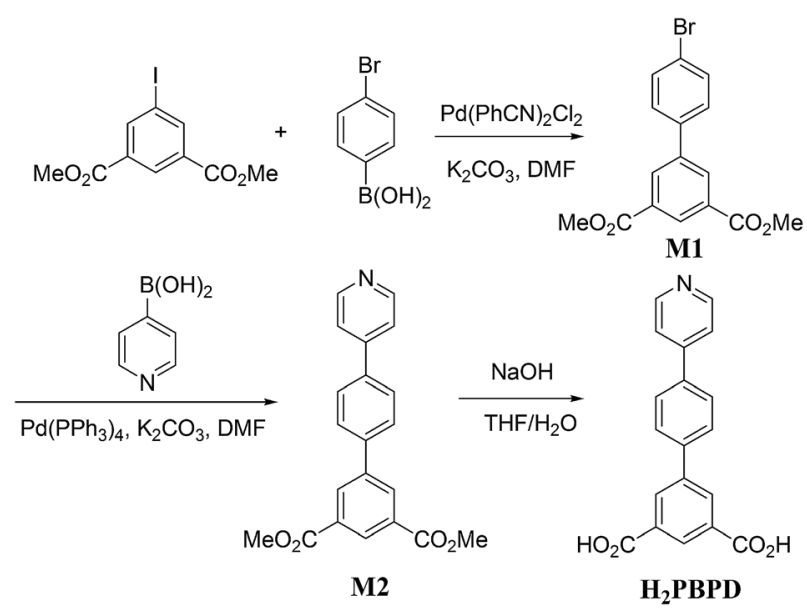

Scheme 1 Design and synthesis of ligand $\mathrm{H}_{2}$ PBPD. 
$61 \%$ yield as a pale solid. ${ }^{1} \mathrm{H} \mathrm{NMR}\left(300 \mathrm{MHz}, \mathrm{CDCl}_{3}\right): \delta=8.70(\mathrm{~s}$, $1 \mathrm{H}), 8.68$ (t, $J=1.5 \mathrm{~Hz}, 2 \mathrm{H}), 8.51$ (d, $J=1.4 \mathrm{~Hz}, 2 \mathrm{H}), 7.82-7.74$ $(\mathrm{m}, 4 \mathrm{H}), 7.58-7.53(\mathrm{~m}, 2 \mathrm{H}), 3.99(\mathrm{~s}, 6 \mathrm{H}) .{ }^{13} \mathrm{C} \mathrm{NMR}(75 \mathrm{MHz}$, $\left.\mathrm{CDCl}_{3}\right): \delta=166.1,150.4,147.5,141.0,139.8,138.0,132.2,131.4$, 129.7, 127.9, 127.7, 121.5, 52.4. Anal. calcd for $\mathrm{C}_{21} \mathrm{H}_{17} \mathrm{NO}_{4}: \mathrm{C}$, 72.61; H, 4.93; N, 4.03. Found: C, 71.62; H, 4.98, N, 3.36. MS m/z: $348.1\left(\mathrm{M}+\mathrm{H}^{+}\right)$.

To this product of $\mathbf{M} 2(0.96 \mathrm{~g}, 2.55 \mathrm{mmol})$, dissolved in THF$\mathrm{H}_{2} \mathrm{O},(1: 1,20 \mathrm{~mL})$ was added $\mathrm{KOH}(1.428 \mathrm{~g}, 25.5 \mathrm{mmol})$ and the resulting solution was stirred under reflux for $24 \mathrm{~h}$. The mixture was acidified with aq. $\mathrm{HCl}$, and then filtered. The pure product $\mathrm{H}_{2}$ PBPD was obtained as a pale yellow solid. ${ }^{1} \mathrm{H} \mathrm{NMR}(300 \mathrm{MHz}$, DMSO- $\left.d^{6}\right): \delta=9.00(\mathrm{~d}, J=6.3 \mathrm{~Hz}, 2 \mathrm{H}), 8.47-8.55(\mathrm{~m}, 5 \mathrm{H}), 8.21$ $(\mathrm{d}, J=8.1 \mathrm{~Hz}, 2 \mathrm{H}), 8.03(\mathrm{~d}, J=8.4 \mathrm{~Hz}, 2 \mathrm{H}) .{ }^{13} \mathrm{C} \mathrm{NMR}(75 \mathrm{MHz}$, DMSO- $\left.d^{6}\right): \delta=166.3,154.7,142.0,141.3,139.6,133.9,132.3$, 131.4, 128.9, 128.0, 123.8. Anal. calcd for $\mathrm{C}_{19} \mathrm{H}_{13} \mathrm{NO}_{4}$ : C, 71.47; $\mathrm{H}, 4.10$; N, 4.39. Found: C, 71.62; H, 4.98, N, 3.36. MS m/z: 320.4 $\left(\mathrm{M}+\mathrm{H}^{+}\right)$.

\section{Synthesis of $\left[\mathrm{Cu}(\mathrm{PBPD})(\mathrm{DMF})_{2}\left(\mathrm{H}_{2} \mathrm{O}\right)_{3}\right](1)$}

A mixture of $\mathrm{Cu}\left(\mathrm{NO}_{3}\right)_{2} \cdot 3 \mathrm{H}_{2} \mathrm{O}(6.05 \mathrm{mg}, 0.025 \mathrm{mmol}), \mathrm{H}_{2} \mathrm{PBPD}$ (7.975 mg, $0.025 \mathrm{mmol})$, DMF (1 mL) and $\mathrm{HNO}_{3}(125 \mu \mathrm{L}, 2.7 \mathrm{M}$ in DMF) was sealed in a $20 \mathrm{~mL}$ vial and heated at $85{ }^{\circ} \mathrm{C}$ for 4 days. After slowly cooling to room temperature, green diamondshaped crystals of 1 were isolated (yield: 25\%). Anal. calcd for $\mathrm{C}_{25} \mathrm{H}_{31} \mathrm{~N}_{3} \mathrm{O}_{9} \mathrm{Cu}: \mathrm{C}, 51.69 \% ; \mathrm{H}, 5.37 \%$; $\mathrm{N}, 7.23 \%$; found: $\mathrm{C}$, $52.11 \%$; H, 4.69\%; N, 7.11\%. IR spectrum $\left(\mathrm{cm}^{-1}\right): 2928(\mathrm{~m})$, 1672(s), 1493(w), 1372(s), 1250(w), 1090(s), 997(w), 912(w), 819(s), 771(s), 725(s), 649(m), 584(w), 491(m).

\section{Stability test for 1}

The as-synthesized sample was soaked in organic solvents such as $\mathrm{CH}_{3} \mathrm{OH}, \mathrm{C}_{2} \mathrm{H}_{5} \mathrm{OH}, \mathrm{CH}_{2} \mathrm{Cl}_{2}, \mathrm{CHCl}_{3}$ and $\mathrm{CH}_{3} \mathrm{CN}$ for more than two months, then filtered and dried for further characterization of PXRD. In addition, the dried as-synthesized samples were heat at different temperature for $30 \mathrm{~min}$ with the heating rate of $5{ }^{\circ} \mathrm{C} \min ^{-1}$, then the PXRD was also measured to characterize the thermal stability.

\section{Sample activation and adsorption measurements}

The solvent-exchange sample was obtained by soaking the assynthesized sample in methanol for three days with methanol refreshing every two hours, and then replace methanol with dichloromethane in the same method for three days. Before gas adsorption measurement, the sample was future activated using the "outgas" function of the adsorption analyzer to remove the guest molecules from the pores by evacuation under a dynamic vacuum at $85{ }^{\circ} \mathrm{C}$ for $10 \mathrm{~h}$. All gases used are of 99.999\% purity throughout the adsorption measurements. Lowpressure nitrogen $\left(\mathrm{N}_{2}\right)$, carbon dioxide $\left(\mathrm{CO}_{2}\right)$ sorption experiments were performed on Micrometrics ASAP 2020 instrument, and methane $\left(\mathrm{CH}_{4}\right)$ sorption experiments were performed on Micrometrics ASAP 2420 instrument. The selectivity of $\mathrm{CO}_{2}$ over $\mathrm{CH}_{4}$ was calculated by using the ideal adsorption solution theory (IAST) ${ }^{15}$ The experiment of $\mathrm{CO}_{2}$ cyclic adsorption and regeneration of compound $\mathbf{1}$ were performed on Perkin-Elmer
TGA Q500 thermogravimetric analyzer. The sample was pretreated at $150{ }^{\circ} \mathrm{C}$ under $\mathrm{N}_{2}$ atmosphere for five hours to remove the guest molecules in the pores. The conditions of test was 25 to $80{ }^{\circ} \mathrm{C}$ at ambient pressure.

\section{Results and discussion}

\section{Crystal structure descriptions}

Single-crystal X-ray structural analysis shows that compound $\mathbf{1}$ possesses 3D neutral framework and crystallizes in the hexagonal space group $R \overline{3}$. The asymmetric unit of 1 contains one independent $\mathrm{Cu}$ atom and one $\mathrm{PBPD}^{2-}$ ligand. As shown in Fig. 1a, the two carboxyl groups of $\mathrm{PBPD}^{2-}$ ligand display the bridging coordination mode to link two $\mathrm{Cu}^{2+}$ ions, and the $\mathrm{N}$ atom of pyridine is coordinated with one $\mathrm{Cu}^{2+}$ ion. Fig. $1 \mathrm{~b}$ shows that two $\mathrm{Cu}^{2+}$ ions are chelated by four carboxylate groups from four different $\mathrm{PBPD}^{2-}$ ligands to form a square paddle-wheel binuclear $\mathrm{Cu}_{2}(\mathrm{COO})_{4}$ cluster, and the axial positions of the cluster are occupied by two pyridine- $N$ donors from another two $\mathrm{PBPD}^{2-}$ ligands. As shown in Fig. 1c, the six-connected paddlewheel clusters are linked together through three-connected $\mathrm{PBPD}^{2-}$ ligands to form a 3D structure, with $1 \mathrm{D}$ channels along the $c$-axis $(8.468 \AA)$. The $\mathrm{Cu}-\mathrm{O}$ bond lengths varies from $1.954(3)$ to $1.970(3) \AA$, the $\mathrm{Cu}-\mathrm{N}$ bond length is $2.188(3) \AA$, and the $\mathrm{O}-\mathrm{Cu}-\mathrm{O}$ bond angles are in the range of $88.50(14)-$ $166.82(11)^{\circ}$ (Table $\mathrm{S} 2 \dagger$ ), which are comparable to those values found in other reported similar compounds. ${ }^{\mathbf{1 6}, 9 \boldsymbol{b}, \mathbf{9 d}}$ There are two types of metal-ligand cages in the framework of compound $\mathbf{1}$. The small cage is constructed by six paddle-wheel $\left[\mathrm{Cu}_{2}\left(\mathrm{CO}_{2}\right)_{4}\right]$ clusters and six $\mathrm{PBPD}^{2-}$ ligands with dimensions of $c a .8 .5 \times$ 15.3 $\AA$ (Fig. 2a). The large cage consists of twelve paddle-wheel $\left[\mathrm{Cu}_{2}\left(\mathrm{CO}_{2}\right)_{4}\right]$ clusters and six PBPD ${ }^{2-}$ ligands with dimensions

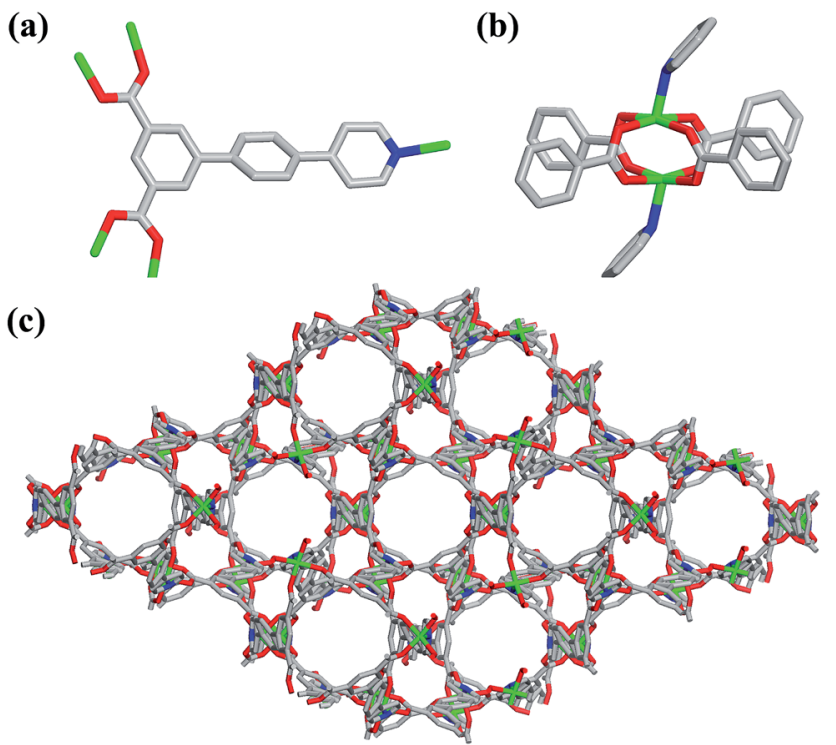

Fig. 1 (a) Coordination modes of carboxyl groups of PBPD ${ }^{2-}$ ligand. (b) The distorted binuclear $\left[\mathrm{Cu}_{2}(\mathrm{COO})_{4}\right]$ motif. (c) View of the 3D porous network along the $c$-axis in compound 1 . All hydrogen atoms were omitted for clarity. 
(a)

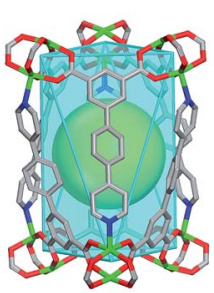

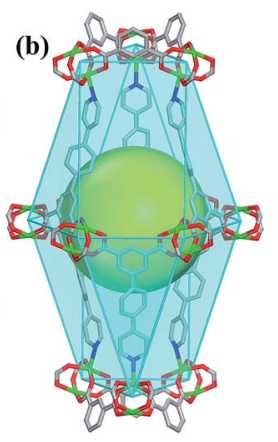

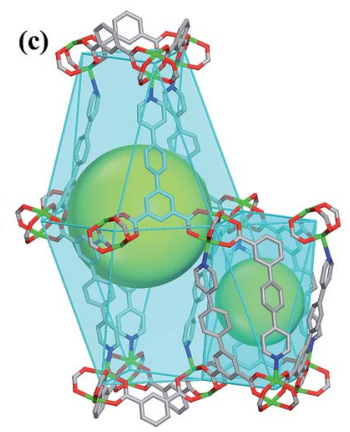

Fig. 2 (a) The cage constructed by six $\left[\mathrm{Cu}_{2}\left(\mathrm{CO}_{2}\right)_{4}\right]$ clusters and six $\mathrm{PBPD}^{2-}$ ligands. (b) The cage constructed by twelve $\left[\mathrm{Cu}_{2}\left(\mathrm{CO}_{2}\right)_{4}\right]$ clusters and six PBPD ${ }^{2-}$ ligands. (c) The stacking mode of two cages.

of $c a .14 .9 \times 32.1 \AA$ (Fig. $2 \mathrm{~b}$ ). These two cages are arranged alternatively to form a cage-stacked 3D framework (Fig. 2c).

Topology analysis is applied in order to better understand the structure of compound 1. If the T-shaped $\mathrm{PBPD}^{2-}$ ligand serve as a 3-connected node (Fig. 3a) and the paddle-wheel cluster serve as a 6-connected octahedral node (Fig. $3 \mathrm{~b}$ ), the resulting structure of compound $\mathbf{1}$ could be simplified as a (3,6)-connected net (Fig. 3c) with the point symbol $\left\{4^{2} \cdot 6\right\}_{2}\left\{4^{4} \cdot 6^{2} \cdot 8^{6} \cdot 10^{3}\right\}$, as calculated by Topos 4.0 .

\section{PXRD and thermal analyses of compound 1}

The powder X-ray diffraction (PXRD) shows good correlation between the simulated pattern from the sing-crystal data and the as-synthesized pattern of compound $\mathbf{1}$ (Fig. S2 $\dagger$ ), indicating
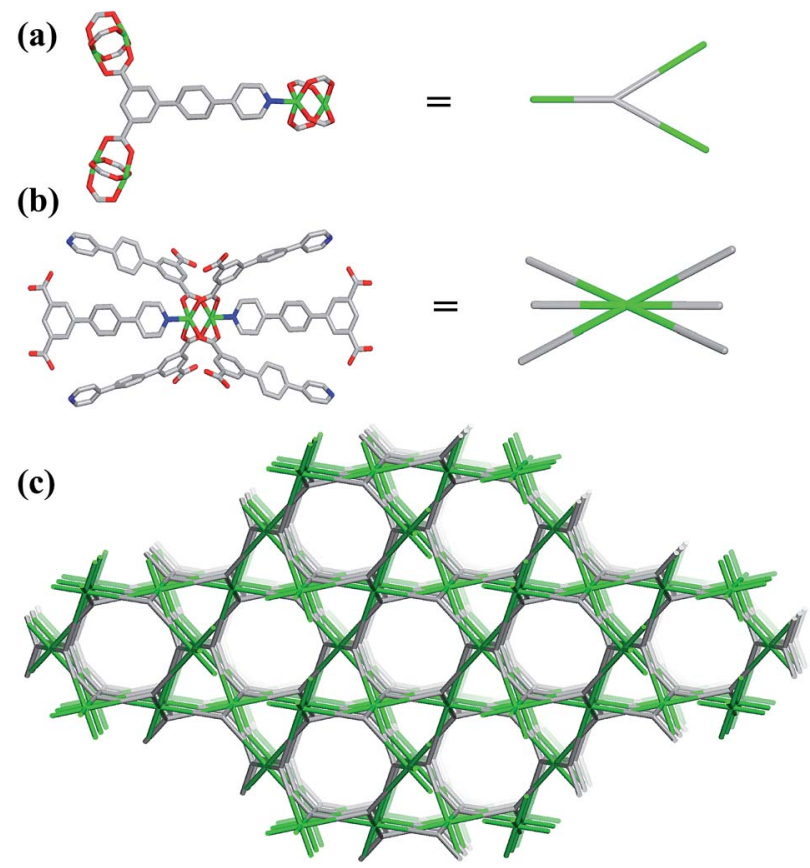

Fig. 3 (a) The simplified 3-connected node of the ligand. (b) The simplified 6 -connected node of the binuclear unit $\left[\mathrm{Cu}_{2}(\mathrm{COO})_{4} \mathrm{~N}_{2}\right]$. (c) The $(3,6)$-connected topological with the symbol of $\left\{4^{2} \cdot 6\right\}_{2}\left\{4^{4} \cdot 6^{2} \cdot 8^{6} \cdot 10^{3}\right\}$ in compound 1 .

that compound $\mathbf{1}$ is in a high pure phase. In order to identify the thermal stability of compound $\mathbf{1}$, the thermogravimetric analyses (TGA) have been carried from room temperature to $800{ }^{\circ} \mathrm{C}$ (Fig. S4†). The results indicate that compound 1 losts its noncoordinated DMF and $\mathrm{H}_{2} \mathrm{O}$ molecules in the temperature range of $20-334{ }^{\circ} \mathrm{C}$. The weight loss of $34.40 \%$ is consistent with calculated one of $34.46 \%$. Then the 3D framework continue to loss weight at higher temperature. The end product of decomposition of compound $\mathbf{1}$ is $\mathrm{CuO}$ with weight percentage $13.62 \%$ (calculated: $13.69 \%$ ).

\section{Stability of compound 1}

To investigate the chemical stability of compound $\mathbf{1}$, we soaked the as-synthesized samples in different organic solvents such as $\mathrm{CH}_{3} \mathrm{OH}, \mathrm{C}_{2} \mathrm{H}_{5} \mathrm{OH}, \mathrm{CH}_{3} \mathrm{CN}, \mathrm{CH}_{2} \mathrm{Cl}_{2}, \mathrm{CHCl}_{3}$ for more than two months. And then to investigate the thermal stability, the assynthesized samples were calcined at different temperature of $150{ }^{\circ} \mathrm{C}, 200{ }^{\circ} \mathrm{C}$, and $250{ }^{\circ} \mathrm{C}$ for $30 \mathrm{~min}$. As shown in Fig. 4 , the PXRD pattern of compound 1 treated in different conditions matched the simulated X-ray pattern derived from the single crystal structure, which confirming the structure was not destroyed when soaked in different solvents and calcined in variable temperature. These results indicate that compound $\mathbf{1}$ possesses high thermal stability. We speculate that the high stability of compound $\mathbf{1}$ due to the strong energy of the coordination bond based on the Hard-Soft-Acid-Base theory (HSAB), the soft-acid metal cations $\mathrm{Cu}^{2+}$ coordinated with soft-base $\mathrm{N}$ donor of $\mathrm{H}_{2} \mathrm{PBPD}$ ligand, forming a much stronger $\mathrm{Cu}-\mathrm{N}$ bonds. This is the reason why the compound $\mathbf{1}$ can keep its structure when soaked in different solvents, calcined at high temperature and expose in the air for several months. The HSAB coordination theory maybe an effective strategy for rationally design and synthesize stable MOFs.

\section{Gas sorption properties}

$\mathbf{N}_{2}$ adsorption. To investigate the permanent porosity of compound $\mathbf{1}$, the $\mathrm{N}_{2}$ adsorption experiments were performed at

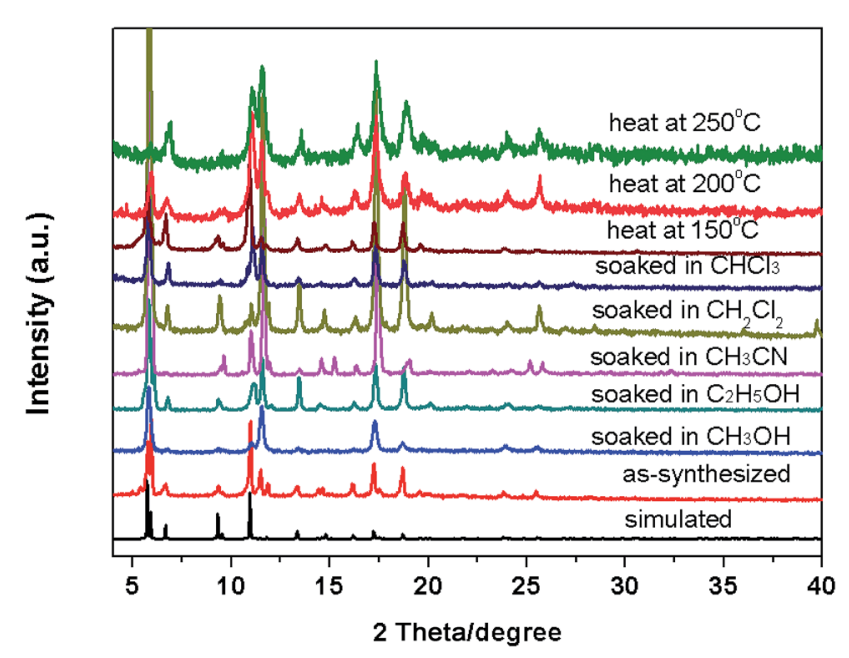

Fig. 4 The PXRD patterns for compound 1 soaked in different solvents and heat in variable temperature. 
$77 \mathrm{~K}$. The as-synthesized compound 1 was activated and measured by the adsorption analyze. As shown in Fig. 5 , the $\mathrm{N}_{2}$ adsorption experiments reveals that compound $\mathbf{1}$ exhibits a typical type-I adsorption isotherm, which is characteristic of microporous materials. The $\mathrm{N}_{2}$ adsorption shows good reversibility. Compound 1 has a total pore volume of $0.70 \mathrm{~cm}^{3} \mathrm{~g}^{-1}$ calculated from the $\mathrm{N}_{2}$ isotherm data. The Brunauer-EmmettTeller $\left(S_{\mathrm{BET}}\right)$ and Langmuir surface areas $\left(S_{\text {Langmuir }}\right)$ are $1682 \mathrm{~m}^{2}$ $\mathrm{g}^{-1}$ and $1992 \mathrm{~m}^{2} \mathrm{~g}^{-1}$, respectively. Under the temperature, the uptake of $\mathrm{N}_{2}$ was $458 \mathrm{~cm}^{3} \mathrm{~g}^{-1}$ at 1.0 atm. The pore size distribution shows that compound 1 possesses three types of pore sizes centered at $0.68 \mathrm{~nm}, 0.80 \mathrm{~nm}$ and $1.00 \mathrm{~nm}$ (nonlocal density functional theory method).

$\mathrm{CO}_{2} / \mathrm{CH}_{4}$ adsorption. In addition, low-pressure $\mathrm{CO}_{2}$ and $\mathrm{CH}_{4}$ sorption experiments for compound 1 were measured (Fig. 6). The sorption isotherms for $\mathrm{CO}_{2}$ reveal that compound 1 can absorb $\mathrm{CO}_{2}$ up to $114 \mathrm{~cm}^{3} \mathrm{~g}^{-1}\left(5.08 \mathrm{mmol} \mathrm{g}^{-1}\right.$ or $\left.22.47 \mathrm{wt} \%\right)$ at $273 \mathrm{~K}$ and $1.0 \mathrm{~atm}$, and $83 \mathrm{~cm}^{3} \mathrm{~g}^{-1}$ (3.70 mmol g ${ }^{-1}$ or $\left.16.43 \mathrm{wt} \%\right)$ at $298 \mathrm{~K}$ and $1.0 \mathrm{~atm}$. The uptake amount of compound $\mathbf{1}$ is much higher than some of well-known MOFs, such as MOF-5 (6.2 wt\%, at $273 \mathrm{~K}$ and $1 \mathrm{~atm}), \mathrm{SUN}-4$ (20.6 wt\%, at $273 \mathrm{~K}$ and $1 \mathrm{~atm}$ ), SUN-21 (18.4 wt\%, at $273 \mathrm{~K}$ and $1 \mathrm{~atm}$ ), MOF-602 (5 wt\%, at $273 \mathrm{~K}$ and $1 \mathrm{~atm}),{ }^{17}$ However, compound 1 can adsorb $45 \mathrm{~cm}^{3}$ $\mathrm{g}^{-1}$ of $\mathrm{CH}_{4}$ at $273 \mathrm{~K}$ and $1 \mathrm{~atm}$, and $22 \mathrm{~cm}^{3} \mathrm{~g}^{-1}$ of $\mathrm{CH}_{4}$ at $298 \mathrm{~K}$ and $1 \mathrm{~atm}$, which is much lower than the uptake of $\mathrm{CO}_{2}$. To predict the selectivity of $\mathrm{CO}_{2}$ versus $\mathrm{CH}_{4}$, we used the ideal adsorbed solution theory (IAST) to calculate the multicomponent adsorption behavior from the experimental puregas isotherms. The adsorption selectivity for $\mathrm{CO}_{2}-\mathrm{CH}_{4}$ mixtures as a function of pressure is presented in Fig. S6. $\uparrow$ The selectivity of $\mathrm{CO}_{2}$ over $\mathrm{CH}_{4}$ reaches a maximum of 6.1 at $298 \mathrm{~K}$ and 1.0 bar, indicating that compound 1 exhibits selectivity to $\mathrm{CO}_{2}$ over $\mathrm{CH}_{4}$. We speculate that compound 1 can selectively adsorb $\mathrm{CO}_{2}$ over $\mathrm{CH}_{4}$ because $\mathrm{CO}_{2}$ has a large quadrupole moment whereas $\mathrm{CH}_{4}$ has none.

To better understand the observations and evaluate the extent of $\mathrm{CO}_{2}$-framework interactions, the $Q_{\mathrm{st}}$ for $\mathrm{CO}_{2}$ at low coverage are calculated by fitting the gas adsorption isotherms

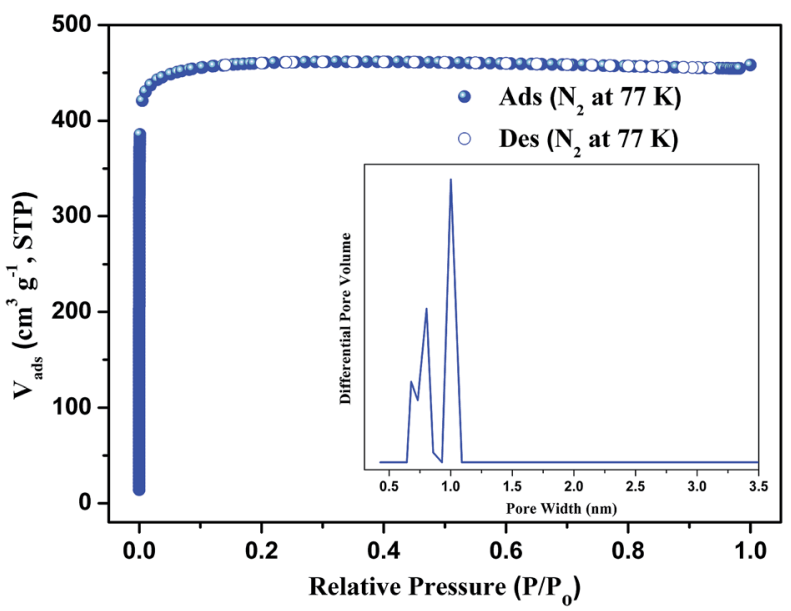

Fig. $5 \mathrm{~N}_{2}$ adsorption and desorption isotherms at $77 \mathrm{~K}$. Inset: pore size distribution of compound 1.

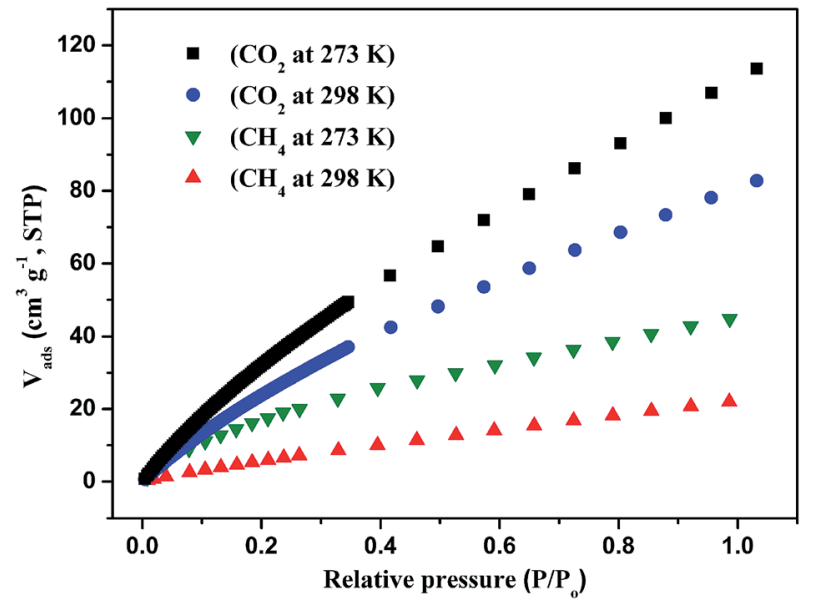

Fig. $6 \mathrm{CO}_{2}$ and $\mathrm{CH}_{4}$ adsorption isotherm of compound 1 at $273 \mathrm{~K}$ and 298 K.

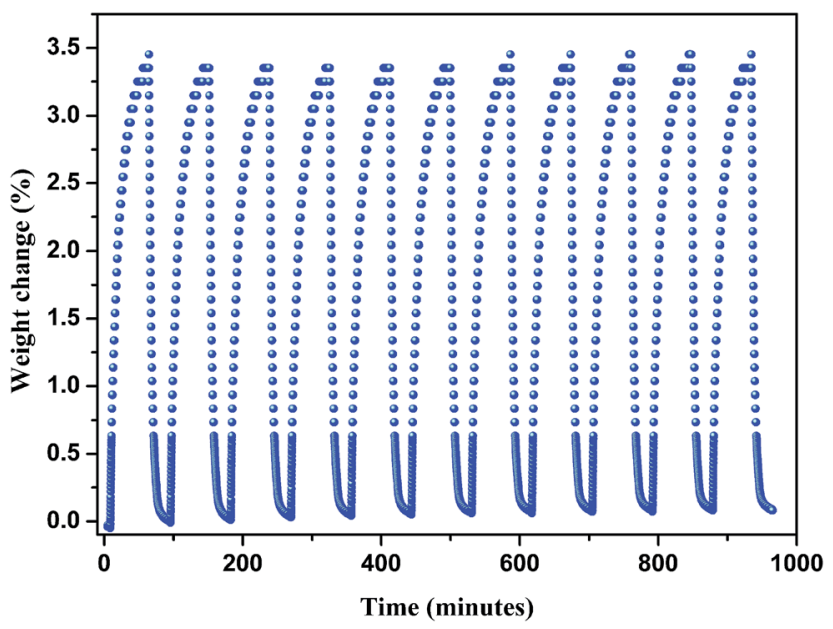

Fig. $7 \mathrm{CO}_{2}$ adsorption/desorption cycles obtained for the compound 1 from 25 to $80^{\circ} \mathrm{C}$.

at $273 \mathrm{~K}$ and $298 \mathrm{~K}$ to the Virial equation. The values are $9.5 \mathrm{~kJ}$ $\mathrm{mol}^{-1}$ for $\mathrm{CO}_{2}$ (Fig. S7 $\dagger$ ). This low $Q_{\text {st }}$ value shows that the interactions between $\mathrm{CO}_{2}$ and the framework of compound $\mathbf{1}$ is weak. The reason maybe because the open metal sites of paddlewheel $\left[\mathrm{Cu}_{2}\left(\mathrm{CO}_{2}\right)_{4}\right]$ are occupied by the pyridin of PBPD ${ }^{2-}$ ligand.

Then we explored the $\mathrm{CO}_{2}$ cyclic adsorption and regeneration of the activated sample under ambient pressure from 25 to $80{ }^{\circ} \mathrm{C}$. As shown in Fig. 7, compound 1 shows a stable $\mathrm{CO}_{2}$ adsorption capacity and no obvious weight change even after more than 10 cycles. Then the PXRD of the sample after $\mathrm{CO}_{2}$ adsorption/desorption cycles was measured, as shown in Fig. S2, $\uparrow$ the structure of compound 1 was still not destroyed, which also confirmed the stability of the framework.

\section{Conclusions}

In summary, a metal-organic framework assembled from $\mathrm{T}$ shaped pyridyl dicarboxylate ligand $4^{\prime}$-(pyridin-4-yl)-[1, $1^{\prime}$ - 
biphenyl]-3,5-dicarboxylic acid ( $\mathrm{H}_{2} \mathrm{PBPD}$ ) have been successfully synthesized via solvothermal reaction with copper(II) nitrate. Structural analyses revealed that compound $\mathbf{1}$ is a three-dimensional framework with $(3,6)$-connected topology. Compound 1 exhibits high stability at high temperature and in organic solvents. In addition, the gas adsorption properties of compound 1 were investigated, $\mathrm{N}_{2}$ adsorption and desorption isotherms at $77 \mathrm{~K}$ indicated that it is microporous materials and with high BET surface area of $1682 \mathrm{~m}^{2} \mathrm{~g}^{-1}$. And it also exhibit outstanding adsorption capacity for $\mathrm{CO}_{2}$ and $\mathrm{CH}_{4}$. It is worth noting that the activated compound 1 exhibits selectivity of $\mathrm{CO}_{2}$ over $\mathrm{CH}_{4}$ at $298 \mathrm{~K}$ and 1 bar, indicating that the materials possesses great potential in $\mathrm{CO}_{2}$ capture and $\mathrm{CO}_{2} / \mathrm{CH}_{4}$ separation. The $\mathrm{CO}_{2}$ cyclic adsorption and regeneration experiments shows that it has a stable $\mathrm{CO}_{2}$ adsorption capacity and no obvious weight change after ten times. These researches reveal that T-shaped pyridyl dicarboxylate ligand has potential applications in building MOFs with high stability and high adsorption capacity.

\section{Acknowledgements}

We thank the National Natural Science Foundation of China (Grants: 21471064, 21641004 and 21621001) for support to this work.

\section{Notes and references}

1 (a) P. K. Thallapally, J. Tian, M. R. Kishan, C. A. Fernandez, S. J. Dalgarno, P. B. McGrail, J. E. Warren and J. L. Atwood, J. Am. Chem. Soc., 2008, 130, 16842; (b) M. P. Suh, H. J. Park, T. K. Prasad and D.-W. Lim, Chem. Rev., 2012, 112, 782; (c) T. Remy, G. V. Baron and J. F. M. Denayer, Langmuir, 2011, 27, 13064; (d) P. Horcajada, C. Serre, G. Maurin, N. A. Ramsahye, F. Balas, M. Vallet-Regí, M. Sebban, F. Taulelle and G. Férey, J. Am. Chem. Soc., 2008, 130, 6774; (e) J. Y. Lee, O. K. Farha, J. Roberts, K. A. Scheidt, S. B. T. Nguyen and J. T. Hupp, Chem. Soc. Rev., 2009, 38, 1450; $(f)$ G. Férey and C. Serre, Chem. Soc. Rev., 2009, 38, 1380; (g) C. Wang, D. Liu and W. B. Lin, J. Am. Chem. Soc., 2013, 135, 13222; (h) L. E. Kreno, K. Leong, O. K. Farha, M. Allendorf, R. P. V. Duyne and J. T. Hupp, Chem. Rev., 2012, 112, 1105.

2 (a) J. R. Li, R. J. Kuppler and H. C. Zhou, Chem. Soc. Rev., 2009, 38, 1477; (b) J. R. Li, J. Sculley and H. C. Zhou, Chem. Rev., 2012, 112, 869; (c) K. Sumida, D. L. Rogow, J. A. Mason, T. M. McDonald, E. D. Bloch, Z. R. Herm, T. H. Bae and J. R. Long, Chem. Rev., 2012, 112, 724.

3 (a) P. Verma, X. F. Xu and D. G. Truhlar, J. Phys. Chem. C, 2013, 117, 12648; (b) H. M. Cheng, Q. H. Yang and C. Liu, Carbon, 2001, 39, 1447; (c) C. E. Holland, S. A. Al-Muhtaseb and J. A. Ritter, Ind. Eng. Chem. Res., 2001, 40, 338; (d) Z. J. Zhang, Z. Z. Yao, S. C. Xiang and B. L. Chen, Energy Environ. Sci., 2014, 7, 2868.

4 (a) H. Li, M. Eddaoudi, M. O'Keeffe and O. M. Yaghi, Nature, 1999, 402, 276; (b) N. Li, J. Xu, R. Feng, T. L. Hu and X. H. Bu, Chem. Commun., 2016, 52, 8501; (c) M. Eddaoudi, H. Li and
O. M. Yaghi, J. Am. Chem. Soc., 2000, 122, 1391; (d) J. R. Li, Y. Tao, Q. Yu, X. H. Bu, H. Sakamoto and S. Kitagawa, Chem.-Eur. J., 2008, 14, 2771.

5 (a) S. C. Xiang, W. Zhou, J. M. Gallegos, Y. Liu and B. L. Chen, J. Am. Chem. Soc., 2009, 131, 12415; (b) X. Lin, I. Telepeni, A. J. Blake, A. Dailly, C. M. Brown, J. M. Simmons, M. Zoppi, G. S. Walker, K. M. Thomas, T. J. Mays, P. Hubberstey, N. R. Champness and M. Schröder, J. Am. Chem. Soc., 2009, 131, 2159; (c) J. K. Sun, M. Ji, C. Chen, W. G. Wang, P. Wang, R. P. Chen and J. Zhang, Chem. Commun., 2013, 49, 1624; (d) Z. X. Chen, S. C. Xiang, H. D. Arman, P. Li, S. Tidrow, D. Y. Zhao and B. L. Chen, Eur. J. Inorg. Chem., 2010, 3745; (e) Z. Y. Guo, H. Wu, G. Srinivas, Y. M. Zhou, S. C. Xiang, Z. X. Chen, Y. T. Yang, W. Zhou, M. O'Keeffe and B. L. Chen, Angew. Chem., Int. Ed., 2011, 50, 3178; (f) Y.-G. Lee, H. R. Moon, Y. E. Cheon and M. P. k. Suh, Angew. Chem., Int. Ed., 2008, 47, 7741; (g) D. Lässig, J. Lincke, J. Moellmer, C. Reichenbach, A. Moeller, R. Gläser, G. Kalies, K. A. Cychosz, M. Thommes, R. Staudt and H. Krautscheid, Angew. Chem., Int. Ed., 2011, 50, 10344; (h) X.-J. Wang, P.-Z. Li, Y. F. Chen, Q. Zhang, H. C. Zhang, X. Xiang Chan, R. Ganguly, Y. X. Li, J. W. Jiang and Y. l. Zhao, Sci. Rep., 2013, 3, 1149. 6 (a) I. Spanopoulos, P. Xydias, C. D. Malliakas and P. N. Trikalitis, Inorg. Chem., 2013, 52, 855; (b) Z. H. Xiang, C. Q. Fang, S. H. Leng and D. P. Cao, J. Mater. Chem. A, 2014, 2, 7662; (c) B. L. Chen, L. B. Wang, Y. Q. Xiao, F. R. Fronczek, M. Xue, Y. J. Cui and G. D. Qian, Angew. Chem., Int. Ed., 2009, 48, 500; (d) Z. M. Hao, X. Z. Song, M. Zhu, X. Meng, S. N. Zhao, S. Q. Su, W. T. Yang, S. Y. Song and H. J. Zhang, J. Mater. Chem. A, 2013, 1, 11043; (e) T. Pham, K. A. Forrest, P. Nugent, Y. Belmabkhout, R. Luebke, M. Eddaoudi, M. J. Zaworotko and B. Space, J. Phys. Chem. C, 2013, 117, 9340; (f) H. Liu, Y. G. Zhao, Z. J. Zhang, N. Nijem, Y. J. Chabal, H. P. Zeng and J. Li, Adv. Funct. Mater., 2011, 21, 4754; $(g)$ H. Liu, Y. G. Zhao, Z. J. Zhang, N. Nijem, Y. J. Chabal, X. F. Peng, H. P. Zeng and J. Li, Chem.-Asian J., 2013, 8, 778.

7 (a) Q. P. Lin, T. Wu, S. T. Zheng, X. H. Bu and P. Y. Feng, J. Am. Chem. Soc., 2012, 134, 784; (b) J. B. Lin, J. P. Zhang and X. M. Chen, J. Am. Chem. Soc., 2010, 132, 6654; (c) J. An, S. J. Geib and N. L. Rosi, J. Am. Chem. Soc., 2010, 132, 38; (d) R. Dawson, E. Stöckel, J. R. Holst, D. J. Adams and A. I. Cooper, Energy Environ. Sci., 2011, 4, 4239.

8 (a) X. L. Zhao and W. Y. Sun, CrystEngComm, 2014, 16, 3247; (b) B. Y. Li, Z. J. Zhang, Y. Li, K. X. Yao, Y. H. Zhu, Z. Y. Deng, F. Yang, X. J. Zhou, G. H. Li, H. H. Wu, N. Nijem, Y. J. Chabal, Z. P. Lai, Y. Han, Z. Shi, S. H. Feng and J. Li, Angew. Chem., Int. Ed., 2012, 51, 1412; (c) B. S. Zheng, J. F. Bai, J. G. Duan, L. Wojtas and M. J. Zaworotko, J. Am. Chem. Soc., 2011, 133, 748; (d) W. Morris, C. J. Doonan, H. Furukawa, R. Banerjee and O. M. Yaghi, J. Am. Chem. Soc., 2008, 130, 12626; (e) S. Kitagawa, R. Kitaura and S. Noro, Angew. Chem., Int. Ed., 2004, 43, 2334; (f) C. Janiak, Dalton Trans., 2003, 2781; (g) S. Kitagawa and R. Matsuda, Coord. Chem. Rev., 2007, 251, 2490. 
9 (a) R. R. Yun, J. G. Duan, J. F. Bai and Y. Z. Li, Cryst. Growth Des., 2013, 13, 24; (b) S. L. Xiang, J. Huang, L. Li, J. Y. Zhang, L. Jiang, X. J. Kuang and C. Y. Su, Inorg. Chem., 2011, 50, 1743; (c) V. Chandrasekhar, C. Mohapatra and R. K. Metre, Cryst. Growth Des., 2013, 13, 4607; (d) M. S. Chen, Z. S. Bai, T. Okamura, Z. Su, S. S. Chen, W. Y. Sun and N. Ueyama, CrystEngComm, 2010, 12, 1935; (e) L. T. Du, Z. Y. Lu, K. Y. Zheng, J. Y. Wang, X. Zheng, Y. Pan, X. Z. You and J. F. Bai, J. Am. Chem. Soc., 2013, 135, 562; ff L. Qin, J. S. Hu, L. F. Huang, Y. Z. Li, Z. J. Guo and H. G. Zheng, Cryst. Growth Des., 2010, 10, 4176; (g) Y. L. Hu, M. L. Ding, X. Q. Liu, L. B. Sun and H. L. Jiang, Chem. Commun., 2016, 52, 5734 .

10 Q. Wang, X. H. Song, M. X. Zhang, W. L. Liu and J. F. Bai, Cryst. Growth Des., 2016, 16, 6156.

11 (a) V. A. Blatov, Struct. Chem., 2012, 23, 955; (b) E. V. Alexandrow, V. A. Blatov, A. V. Kochetkov and D. M. Proserpio, CrystEngComm, 2011, 13, 3947.
12 SAINT, version 6.02a, Bruker AXS Inc., Madison, WI, USA, 2000.

13 G. M. Sheldrick, Acta Crystallogr., Sect. A: Found. Crystallogr., 2008, 64, 112.

14 A. L. Speak, J. Appl. Crystallogr., 2003, 36, 7.

15 J. H. Chen, L. S. Loo and K. Wang, J. Chem. Eng. Data, 2011, 56, 1209.

16 (a) A. Karmakar, L. M. D. R. S. Martins, S. Hazra, M. F. C. G. Silva and A. J. L. Pombeiro, Cryst. Growth Des., 2016, 16, 1837; (b) Y. Xiong, Y. Z. Fan, R. Yang, S. Chen, M. Pan, J. J. Jiang and C. Y. Su, Chem. Commun., 2014, 50, 14631.

17 (a) K. S. Walton, A. R. Millward, D. Dubbeldam, H. Frost, J. J. Low, O. M. Yaghi and R. Q. Snurr, J. Am. Chem. Soc., 2008, 130, 406; (b) Y. G. Lee, H. R. Moon, Y. E. Cheon and M. P. Suh, Angew. Chem., Int. Ed., 2008, 47, 7855; (c) T. K. Kim and M. P. Suh, Chem. Commun., 2011, 47, 4258; (d) H. Furukawa, J. Kim, N. W. Ockwig, M. O'Keeffe and O. M. Yaghi, J. Am. Chem. Soc., 2008, 130, 11650. 